\title{
Simultaneous aortic and pulmonary artery aneurysms due to giant cell arteritis
}

\author{
AR DENNISON, RM WATKINS, AJ GUNNING \\ From the Department of Cardiothoracic Surgery, John Radcliffe and Churchill Hospitals, Oxford
}

Giant cell arteritis may occasionally affect the aorta and larger pulmonary arteries. This can be part of a systemic disease such as necrotising sarcoid granulomatosis or systemic lupus erythematosus, but may also be due to specific conditions, particularly disseminated temporal arteritis (giant cell arteritis). When the pulmonary arteries alone are affected they are usually medium sized and affected as part of a generalised connective tissue disorder such as rheumatoid arthritis. Takayashu's disease may also affect the larger elastic pulmonary arteries or the main pulmonary trunk. This paper describes a previously unreported condition of aneurysmal dilatation of the ascending aorta and main pulmonary trunk with no concomitant generalised connective tissue disorder.

\section{Case report}

A 55 year old woman was admitted to hospital after six months of increasing fatigue, three months of shortness of breath, and two recent episodes of paroxysmal nocturnal dyspnoea, although she had no chest pain. She gave no history of rheumatic or scarlet fever.

The jugular venous pressure was normal, the pulse regular ( 82 beats/minute) but collapsing in nature, and the blood pressure $150 / 50 \mathrm{~mm} \mathrm{Hg}$. All peripheral pulses were present. There was moderate left ventricular enlargement. Both heart sounds were present and in the aortic area there was an ejection systolic murmur and a loud diastolic murmur.

The results of laboratory tests for rheumatoid arthritis, systemic lupus erythematosus, and syphilis were negative. The erythrocyte sedimentation rate (ESR) was $12 \mathrm{~mm}$ in one hour (Westergren). An electrocardiogram showed sinus rhythm with evidence of left ventricular hypertrophy. The chest radiograph showed cardiomegaly with a left ventricular configuration. Cardiac catheterisation (from the right leg and right arm) showed the following pressures $(\mathrm{mm} \mathrm{Hg})$ on the right side of the heart: right atrium $\mathrm{a}=12$, $x=0$, mean 8 ; right ventricle $24 / 4$; main pulmonary artery $24 / 66$, mean 16 ; pulmonary artery wedge mean 10 ; aorta $150 / 50$, mean 90 .

It was not possible to enter the left ventricle but the aortogram showed considerable aortic valve regurgitation. The left coronary artery was entered but the right could not be found. On the basis of these findings it was decided to perform an aortic valve replacement.

Aneurysmal changes of the ascending aorta and main

Address for reprint requests: Mr AJ Gunning, John Radcliffe Hospital, Oxford OX3 9DU.

Accepted 3 October 1984 pulmonary trunk were found. An exudate over the aorta suggested recent active inflammation. The pulmonary artery was extremely thin and densely adherent to the aorta, so that an adequate plane of cleavage could not be found. Dilatation of the aorta continued up to the beginning of the arch and similar pulmonary dilatation was present to the bifurcation of the artery, with considerable thinning of the wall. The right pulmonary artery appeared normal. Frozen section biopsy specimens from both arteries showed active giant cell arteritis. The aortic valve cusps were thickened, allowing considerable regurgitation.

The aortic valve was resected and replaced with a $23 \mathrm{~mm}$ Björk-Shiley valve. The aorta was divided longitudinally and replaced with a $32 \mathrm{~mm}$ preclotted Dacron graft from the level of the innominate artery to just above the valve. Similarly the pulmonary artery was divided longitudinally (revealing multiple areas of dissection), and replaced from the bifurcation to just above the valve cusps. Subsequent histological examination confirmed the findings from the frozen sections.

The patient made a satisfactory postoperative recovery and remained well for three years, with no evidence of recurrent aneurysm formation or valvular incompetence.

Histological examination showed the pulmonary artery to be thinned, with a considerable quantity of metachromatic material in the wall. One part of the arterial wall showed early dissection. In the adventitia there was a striking degree of granulomatous arteritis in the form of appreciable adventitial lymphocytic infiltration, with penetration of the media and disruption of the elastic lamina by giant cell granulomas (fig 1). These granulomas contained pre-

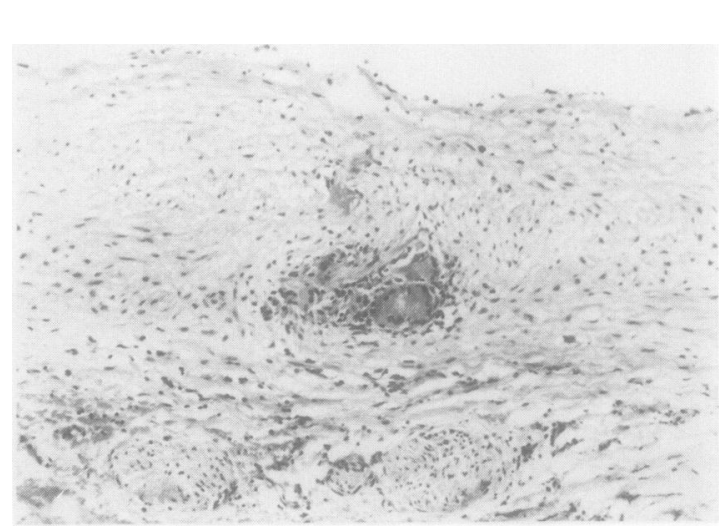

Fig 1 Pulmonary artery wall showing granulomas containing histiocytes and multinucleate giant cells. (Haematoxylin and eosin, $\times 175$.) 


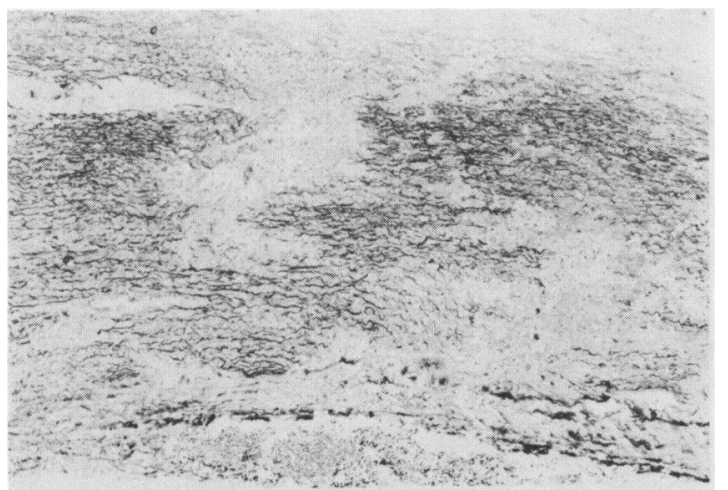

Fig 2 Aorta with total disorganisation of the elastic lamina in the media associated with granulomata and metachromatic material. (Elastic stain, $\times 75$.)

dominantly histiocytes and lymphocytes, but multinucleate giant cells of the Langerhans variety were also very prominent.

Throughout the aortic wall there was a considerable increase in metachromatic material, and a preparation stained for elastin showed total disorganisation of the elastic lamina in the media associated with the granulomas and metachromatic material. The intima showed fibrosis (fig 2).

\section{Discussion}

Giant cell arteritis is a rare cause of aneurysmal dilatation of the aorta' but aneurysmal dilatation of the main pulmonary trunk and aorta concomitantly is not described.

Histological features in this condition resemble temporal arteritis, with medial inflammatory changes and destruction of muscular and elastic fibres of the aortic wall. Langerhans giant cells are usually prominent in the aortitic form of this condition. ${ }^{2}$

Giant cells may also be found in pulmonary arteritis when the condition is isolated or is part of a generalised connective tissue disorder. ${ }^{3}$ When discrete sarcoid granulomas are absent this is almost always a form of Takayashu's disease or a manifestation of the disseminated form of "temporal" arteritis. Temporal arteritis and Takayasha's disease are difficult to differentiate but the former classically affects the muscular arteries in an older age group ${ }^{4}$ whereas Takayasha's disease usually affects the elastic arteries in young adults. ${ }^{5}$ Necrotic lesions surrounded by chronic inflammation and giant cells may also be found limited to the aorta and great vessels ${ }^{6}$ in "idiopathic medial aortopathy".?

In all these conditions the inflammatory process results in loss of the elastic properties of the media of the affected vessels. This results in dilatation and ultimately aneurysm formation. Dissection occurs particularly if hypertension is present, ${ }^{8}$ and rupture and sudden death has been described.9 Lupi-Herrera et al reviewed 107 cases of
Takayashu's disease over 19 years and found that the form in which the ascending aorta was affected (27\%) was usually confused with coarctation and they described no cases of aneurysm formation. 5 Early and uncomplicated lesions are often detected only with difficulty at postmortem examinations. ${ }^{10}$ With pronounced aortic dilatation presentation is usually because of symptomatic valvular incompetence."

The diagnosis is often difficult but with aortic regurgitation of rapid onset, if there is a raised ESR, negative results in serological tests for syphilis, and no history of rheumatic fever, giant cell arteritis should always be considered. A history of temporal arteritis can also often be detected in these patients (five of 11 in Harris's series in 1968. )

Our patient presented with aortic incompetence but serology and ESR were normal. We believe that the lesions of the pulmonary artery and aorta were isolated forms of a giant cell arteritis and not typical of any previously described condition. The patient died three years later but unfortunately necropsy was denied.

Aortitis has previously been treated by prosthetic graft replacement without steroid cover ${ }^{1112}$ and with no subsequent evidence of progression of the disease. " Despite the reticence about the use of Dacron in arteritis and aneurysm, results so far show no contraindications, although most patients have had a shorter follow up than the three years ours had.

\section{References}

1 Austen WG, Blennerhasset JB. Giant-cell aortitis causing an aneurysm of the ascending aorta and aortic regurgitation. $N$ Engl J Med 1965;272:80-3.

2 Cooke WT, Cloake PCP, Govan ADT, Colbeck JC. Temporal arteritis: a generalised vascular disease. $Q J$ Med 1946;15:4776.

3 Wagenaar SSC, Westermann CJJ, Corrin B. Giant cell arteritis limited to large elastic pulmonary arteries. Thorax 1981;36: 876-7.

4 Klein RG, Hunder GG, Stanson AW, Sheps SG. Large artery involvement in giant cell (temporal) arteritis. Ann Intern Med 1975;83:806-12.

5 Lupi-Herrera E, Sanches-Tores G, Marcushamer J, Mispireta J, Horwitz S, Vela JE. Takayasu's arteritis. Clinical studies of 107 cases. Am Heart J 1977;93:944-103.

6 Heggtveit HA, Hennigar GR, Morrione TG. Panaortitis. Am J Pathol 1963;42:151-65.

7 Marquis Y, Richardson JB, Ritchie AC, Wigle ED. Idiopathic medial aortopathy and arteriopathy. Am J Med 1968;44:93954.

8 Harris M. Dissecting aneurysm of the aorta due to giant cell arteritis. Br Heart J 1968;30:840-4.

9 Ainsworth RW, Gresham GA. Giant cell aortitis with rupture of the aorta. J Pathol Bacteriol 1961;82:203-5.

10 Gula G, Pomerance A, Bennet M, Yacoub MH. Homograft replacement of aortic valve and ascending aorta in a patient with non-specific giant cell aortitis. Br Heart J 1977; 39:581-5.

11 Kent DC, Arnold $\mathrm{H}$. Aneurysm of the aorta due to giant cell aortitis. Successful surgical correction. J Thorac Cardiovasc Surg 1967;53:572-7.

12 Zumbro GL, Henley LB, Treasure RL. Saccular aneurysm of ascending aorta caused by granulomatous aortitis in a child. $J$ Thorac Cardiovasc Surg 1975;69:397-4401. 